\title{
Resisting Sexual Colonization, Reclaiming Denied Spaces: A Reading of Tattooed with Taboos: An Anthology of Poetry by Three Women from Northeast India
}

\author{
Anindya Syam Choudhury ${ }^{1} \&$ Amrita Bhattacharyya ${ }^{2}$ \\ ${ }^{1}$ Associate Professor, Department of English, Assam University, Silchar, Assam. \\ ORCID ID: https://orcid.org/oooo-0oo3-0365-9663. Email: anindyasyam@yahoo.com \\ ${ }^{2}$ Assistant Professor, AISER, Amity University, Kolkata, West Bengal. \\ ORCID ID: https://orcid.org/oooo-ooo1-6529-3842.Email:arushi.asmi13@gmail.com
}

\begin{abstract}
In the pervasiveness of the dominant male voices in literature, the resistant female voices have traditionally got drowned. This has made the act of identification and foregrounding of the works of women an important political act, enabling women to gain agency by focusing attention on the silences and taboos on their bodies, sexualities, desires and pleasures thereby disrupting the hegemonic patriarchal establishment. It is in this context that this paper attempts to make a reading of Tattooed with Taboos: An Anthology of Poetry by Three Women from Northeast India, a collection of seventy-seven poems which tries to understand what it means to be a woman in a society fettered with the shackles of patriarchy. The resistance in the anthology (first published in 2011), complied by poets who hail from a peripheral province in the Indian nation-state, begins with the cover design, which powerfully foregrounds a picture of the hem of a phanek (a traditional sarong-like dress worn by women in Manipur), which, because of the norm created by the social matrix of the patriarchal Manipuri society, is regarded as inauspicious and untouchable for the menfolk because of its association with the body of the woman. The paper endeavours to explore how the picture of a vilified piece of dress, symbolising the social control of women's bodies, becomes in the hands of these women poets potent cultural capital as they go about resisting in/through their poetry the sexual colonisation of their bodies and the smothering of their desires by a patriarchal society. In this context, the paper attempts to look at how the poets in this anthology try to re-historicise the pain, sufferings and trauma inscribed on the 'abject' bodies of women by questioning the existing discourse and trying to find a new way of viewing/writing their bodies. This endeavour on the part of the poets, as this paper tries to show, leads them to express a desire to trespass into spaces usually denied to women in the personal and the public.
\end{abstract}

Keywords: Abject bodies, Northeast India, poetry, resistance, sexual colonization

In the last few decades, though several anthologies of women's writings have been published in India, two significant ones (published in the 1990s) which marked a watershed in the history of women's writings in India were the two volumes of Susie Tharu and K Lalita's Women Writing in India: 6oo B.C. to the Present (1991-1993) and Lakshmi Holmström's The Inner Courtyard: Stories by Indian Women (1990). These publications, as Jalil and Sengupta (2019) in the introduction to their anthology titled Women's Writings from India, Pakistan and Bangladesh: The Worlds of Bangla and Urdu point out, went a long way in helping to create "an ambient ecosystem for women writers, formidable in their craftsmanship as well as in their political and social awareness" (p. xx). The generalised project of these anthologies of women's writings has primarily

(c) AesthetixMS 2020. This Open Access article is published under a Creative Commons Attribution Non-Commercial 4.o International License (http://creativecommons.org/licenses/by-nc/4.o/), which permits non-commercial re-use, distribution, and reproduction in any medium, provided the original work is properly cited. For citation use the DOI. For commercial re-use, please contact editor@rupkatha.com. 
been what Tharu and Lalita point out in the general introduction (common to both the volumes) to their anthology: to read "women's writings...as documents in the embattled practices of self and agency, and in the making of a habitable world, at the margins of patriarchies", and to read them "for the gestures of defiance or subversion implicit in them" (1993, Vol. 2, p. 39, emphasis in original). This act of identification, documentation, re-presentation of women's writings, which have usually tended to get submerged and, thereby, marginalized in the pervasiveness of the dominant male voices in literature, then, becomes a polemical political act enabling women to gain agency by focusing attention on the silences and taboos on their bodies, sexualities, desires and pleasures thereby disrupting the hegemonic patriarchal establishment, whose values and structures have hitherto been considered axiomatic. It is in this tradition of women's writings having subversive connotations that the anthology under consideration in this paper, Tattooed with Taboos: An Anthology of Poetry by Three Women Poets from Northeast India, belongs.

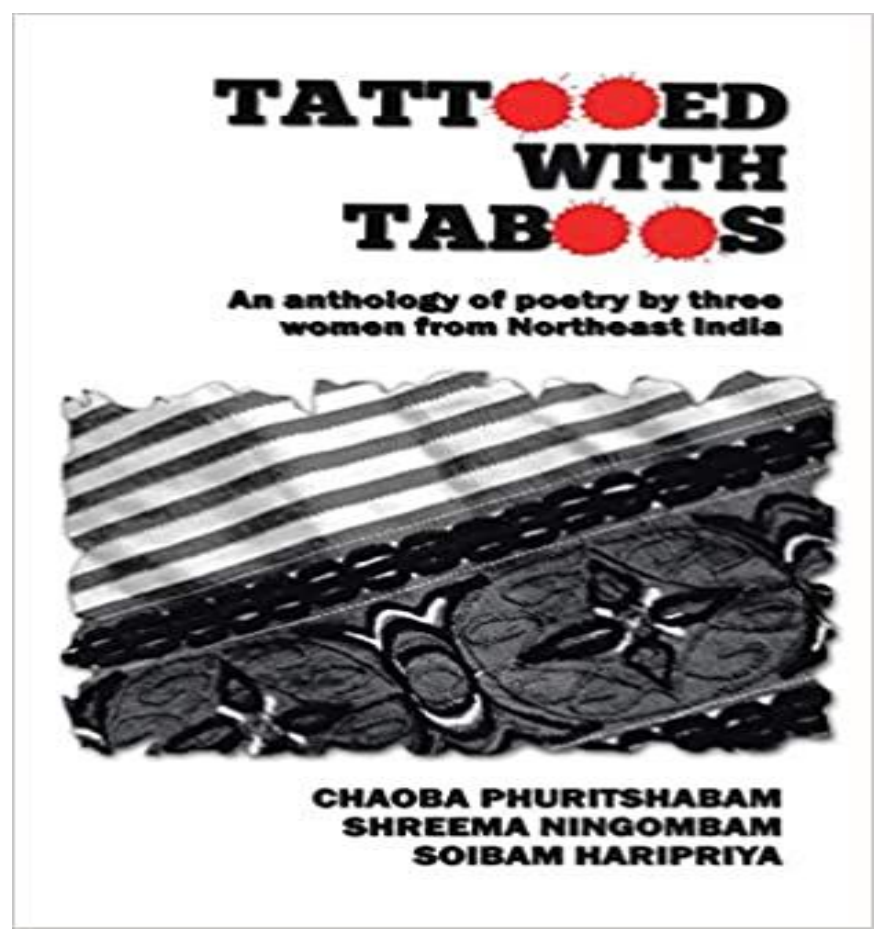

Figure 1: Phuritshabam, Chaoba, et al.(2011) Tattooed with Taboos: An Anthology of Poetry by Three Women from Northeast India [Cover], New Delhi: Partridge India.

Published in 2011, this anthology is a collection of seventy-seven poems written by three women poets - Chaoba Phuritshabam, Shreema Ningombam and Soibam Haripriya - hailing from the state of Manipur in Northeast India. The seventy-seven poems are thematically divided into three sections - 'Tattooed with Taboos', from which the anthology gets its name, 'Angst for Homeland' and 'Love and Longingness' - and it is the first section which, as the poets point out in their introduction to the anthology, "rejoices in sexuality, desire and waywardness in an unbound way", that this paper primarily deals with (p. 1). This section comprises poems which resist in no uncertain terms the attempts of the patriarchal society to smother "in whispers issues of sexuality" by relegating them to "the category of dark things" by assigning them terms like "amotpa", "amangba" and "choukhattaba", which are Meitei terms for 'dirt', 'impure' and 'uncivilised' respectively (p. 5). The options for these women poets are clear: either to live with their bodies "in subservient ways" or challenge the norms "in subversive ways" (Sabala and Gopal, 
2010, p. 43). They choose the latter, beginning the resistance in their anthology with the cover design itself. The cover powerfully foregrounds a picture (Figure 1) of the hem of a phanek (a traditional sarong-like dress worn by women in Manipur), which has usually been regarded as an icon of resistance by Manipuri women against oppression of various kinds, be it the two nupi lans (women's wars) during the colonial period, when the phanek-clad Manipuri women protested against the tyrannical policies of the state, or be it the more recent nude protest by twelve elderly women in 2004 in which they expressed their deep anguish over the rape and murder of the political activist, Thangjam Manorama, by military personnel by disrobing themselves of their phaneks, an act pointing towards the disempowering of women and the society at large by the excesses of the state which seems to be drunk with power thanks to its having in its possession what is often regarded as a set of repressive policies like the Armed Forces (Special Powers) Act (AFSPA) (Ningthoujam 2020).

It is perhaps pertinent to point out here that the phanek occupies a rather liminal space between sacredness and sacrilege in Manipuri society. On the one hand, it is looked upon as a venerated object, symbolising 'the virtue of purity' associated with 'ideal womanhood', and is thereby akin to other kinds of women's dresses (elsewhere), the wearing of which makes women's bodies become carriers of essential traditional culture valorized by patriarchy. Dress, then, becomes "a symbol of social control as it controls the external body" of women while the internal body is controlled more subtly by muffling their voices and desires (Arthur, 1998, p. 77). In this sense, the phanek could be regarded as a tool in the hands of patriarchy to control the female body, which is treated as a metaphor for the community, representing its honour, which has to be upheld at any cost. In another sense, the phanek is often regarded as inauspicious and "untouchable" for the menfolk (Haripriya, 2018, p. 227) because of its association with the body of the woman so much so that lashing by the phanek is used as a popular mode of protest in Manipur to punish men, especially policemen and military personnel, who are regarded as representing the primary masculine sites of oppression. This act of 'phanek bashing', which is believed to have an emasculating effect on men, robbing them of their masculinity, thereby feminisng them, is often celebrated as an empowering act of resistance by women. However, a contrarian position is taken by the scholar Kumam Davidson (2015), who wonders whether this kind of 'phanek feminism', as he calls it, is not after all "a perpetuation of the idea that feminisation is a state of powerlessness". Be that as it may, this often valorized and often vilified piece of dress becomes in the hands of these women poets of Tattooed with Taboos potent cultural capital as they go about resisting in/through their poetry the sexual colonization of their bodies and the smothering of their desires by a patriarchal society. Poetry, in the hands of these poets, "is not a luxury", to quote from Audrey Lorde's path-breaking essay "Poetry is not a Luxury", but "a vital necessity" of their existence, "first made into language, then into idea, and then into more tangible action" (2007, p. 37). In her essay, Lorde conceptualises poetry as consciousness-raising whereby the subjective is made objective, making the inner world of personal experience available for public political discussion (Reed, 2005, p. 78).

In several poems of the anthology, like Soibam Haripriya's "Five Days' Untouchable" and Shreema Ningombam's "One Last Time", "Unburdening the Dead Spirits", "In Defiance" and "To the Ema Lairembi", the sexual politics of the phanek comes through clearly as the poets celebrate the so-called uncleanliness and inauspiciousness of the phanek. In the poems mentioned above and several others, which will be taken up for detailed discussion in the subsequent sections of the paper, the poets do not merely focus attention on cultural symbols like the phanek but they turn their dissenting gaze towards the sexually colonized female body and the experiences felt by it, repudiating in the process the attempts of patriarchal mechanisms to subjugate women into 
conforming to the 'Angel in the House' image. Instead of accepting in an unquestioning way their existence in the world as inferior, passive and dependent beings, these poets yearn for the emancipation of women's desires by transgressing the bounds set forth by conventional norms of morality.

One of the foci of the poems in the anthology is the thematisation of the experiences of violence that women in Manipur have had to face in the course of their interaction with both the state and their society and families (in so far as kinship, marriage and sexuality are concerned). The response of these poets has been like the one of Sumi, the protagonist of Shashi Deshpande's novel A Matter of Time (1996). Like Sumi, who expresses her intention of writing about Surpanakha, who, according to her, was "neither ugly nor hideous, but a woman charged with sexuality, not frightened of displaying it" (Deshpande, 1996, p. 191), these women poets decide to make a conscious decision to resist patriarchy by attempting to construct an alternative counterhegemonic discourse in the socio-cultural spheres of their existence by using their bodies to explore the hitherto tabooed areas of their lives.

In the poem "Sublime" by Shreema Ningombam, the poet begins with a tone inducing a sharp disengagement from the worldly affairs. The subject collects all the pebble-like mundane moments of her life and descends into the "waiting river" (Phuritshabam et al., 2011, p. 39). The nature of the waiting river has been clarified by the poet in the next line in which the river has been portrayed through a metaphor of a "deep tranquil womb" (p. 39). The next stanza also ensures a retreat to the origin of her existence. The poem sharply criticizes women's position in the patriarchal world, but surprisingly, the female subject in this poem is shown to be placed on a higher platform in the societal hierarchy. Patriarchy has placed her on the altar to be worshipped as a mother. This apparent exaltation of the woman to a high position in the hierarchy in this context does not elevate her status in reality; rather, this act of elevating women in the social sphere could be looked upon as another potential ploy of patriarchy to control the position of women, and it must be remembered here that motherhood, as Haripriya (2018, p. 222) notes "is privileged only when it meets the stringent rules of patriarchal society" in which no transgressions are allowed. In the poem, the glory of motherhood that has been paralleled with the grandeur of the divine existence of a goddess has, in fact, been shown to have chained the woman to the set matrices of patriarchy that have in turn robbed her of her individual desires and sense of freedom that she is expected to enjoy as a human being. In the third stanza of the poem, the woman is called the "mistress of the world", an expression with a distinct negative connotation showing perhaps the exasperation of the poet as she sees the woman barely managing to survive under the surveillance of the patriarchy (39). The engulfing patriarchy eats her up and she is "left/Naked and coiled like a foetus" that "[r]ebels without armour" against the exploitative forces around her (39). The speaker in the poem desires for love but then asks a rhetorical question - "Has the sacred ever been loved?" - which prompts the readers to possibly infer that the apparent elevated position of the woman (which she calls 'sublime') is merely a façade; in reality, she is "forbidden to touch/ forbidden to love" (39). The last part of the poem sets out to nullify the hierarchical boundaries in two-fold ways: first, between the man and woman and, secondly, between the human and the divine through a series of questions:

Who knows a goddess' loneliness?

Who knows her hunger for earthly love?

Who knows her yearning to be mundane?

Who knows that goddess too fear? 
Who knows that stone also bleeds?

Who knows that mute does speak? (p.40)

The human identity has been glorified and preferred over all other identities, be it from the perspective of gender or divinity. Another poem of Shrrema Nigombam, "To the Ema Lairembi", is a perfect example of how women can use their bodies to resist the hegemonic patriarchal discourse. Ema Lairembi, the mother goddess is questioned by the poetic persona regarding the latter's lack of access to the goddess during the period of her menstruation to perform her religious duties and to enjoy the right to participate in the religious discourse. She is not allowed to offer flower to the goddess due to her being "impure" during the days of menstruation. The speaker asks the goddess whether because of her being a deity the latter is "free from this flow" of menstrual blood, going on to point out how her traditional outfit mapannaiba phanek "will not be waist up tonight" (p. 59). The phanek, that often vilified piece of dress because of its association with the menstruating female body, as has been pointed out earlier, represents the process through which female bodies are objectified, stigmatized and colonized. The foregrounding of the phanek and the posing of several questions by the speaker in the poem challenge the normative discourse of patriarchy and create a strong resistance against the valorized traditional value system, exhibiting the speaker's attempts at constructing an alternative discourse of existence. The last few lines of this poem open up an exclusive existential space for women by nullifying the binary oppositions and hierarchies set by the patriarchal structure of the society:

Mother, tell them

We are your children

Neither pure not impure

Neither full nor empty

Neither true nor false

Just beings. (p. 59)

The speaker identifies herself and her ilk as "children" of the mother goddess and this identification resists the hierarchy. If a man can avail the opportunities to worship the Goddess at any point of time in a month, there is no point in barring a woman from doing so. The speaker claims an existence that goes beyond any gender constraints. She identifies women as "[n]either pure nor impure/ [n]either full nor empty/ [n]either true nor false" but just as "beings" who, like their male counterparts, hold every contradiction within and thus transcend the confined gender roles framed by the patriarchy.

In Ningombam's "One Thousand and One Nights", the poet makes an effort to portray her body as a site in which the narrative of the conjugal existence can be recorded. The "ultimate celebration/ Of making a life/ A life within another life" is possible only when both the partners devote themselves to the act of creation (p. 6o). The vivid imagery depicts in an uninhibited way the process of writing stories of their union with the "pen" of the partner's "fingertips" and the "ink" of his "passion" (p. 6o). She does not want the story of the night to be recorded in letters and not to be "told by lips" (p. 6o). The darkness of the night is easily perceptible through the interplay of the sensory perceptions. The speaker here wisely chooses some of the sensory organs over others. The optical, auditory and gustatory senses have been suppressed in the narrative while the speaker carefully highlights two sensory organs: the olfactory and tactile ones. The 
entire process of writing the experience of the lovers is recorded through the smelling of the "scent" of their skins and the feeling of the "mingling moisture" of their "breath" (p. 6o). The entire process of creation desires to stain the "white sheet of morality" (p. 6o). The concept of 'whiteness' is attached with the normative value of the society, and the idea of morality is in sync with the pervasive structure of patriarchy. The speaker invites the male partner to play the role of a co-actor in challenging against this set hierarchy of patriarchy. The last stanza speaks about the speaker's experience of their post-consummation phase. The reference to the "stained phanek" again establishes the predominance of bodily existence over psychic in the socio-cultural spheres. Although the narrative of the poem deals with the bodily experiences of the lovers, it surprisingly paves the way for the readers to experience the space beyond it. The patriarchal obsession with the female body has been questioned indirectly. The body which has been objectified and stigmatized by patriarchy regenerates itself by being a strong weapon against the same, thereby unsettling its traditional cultural representations. The speaker being permeated with the smell of the "stained phanek" appears to be an assertive individual who holds the power to give up "[a]ll those illusions betrothed" to her at the time of the "birth of a woman" (p. 61). The woman is not here a marginalized individual who laments her lost space in the socio-cultural sphere; instead, she comes up as an assertive voice who can throw away all sorts of cultural impositions as illusions since she knows that these illusions have been set, framed and utilized by patriarchy in order that it can survive and thrive. This knowledge places her at the centre of the epistemological structure that in turn creates an alternative paradigm of existence for women in the social, cultural and political spheres.

Soibam Haripriya's "Five Days' Untouchable” begins with a powerful questioning of both (what is often regarded as) the patriarchal moorings of the Genesis story in the Bible concerning the origin of women and the traditional denigration of menstruation, which has always been kept in the margins by patriarchy:

Is this blood of life

Merely to mark me impure

For Genesis says

I am not a creator, but created,

Created from a man? (p. 18)

The social status of women has often been thought to have been deprecated through the representation of Eve's origin in the Bible, and the reference to it in the poem in juxtaposition with the image of menstrual blood brings to fore the idea regarding how in many traditions "menstrual blood is associated with immorality or accursedness due to Eve's temptation of Adam" (Green-Cole, 2020, p. 787). The speaker questions this gendering of blood (Lupton, 1993, p. 3) by the society whose "values transform it into female, dirty, discharge, abject, shame" (Green-Cole, 2020, p. 787). The cultural practice of the ostracization of the menstruating woman and her phanek, whereby both are rendered 'untouchable' and 'impure', is lamented upon by the speaker in the second stanza of the poem:

For five days

Quarantined from the rest

By this unholy fluid 


$$
\begin{gathered}
\text { Wrapped with untouchable phanek } \\
\text { Phanek after Phanek } \\
\text { Carrying my untouchable-ness } \\
\text { Accursed piece of cloth } \\
\text { Contaminated for a lifetime. (p. 18) }
\end{gathered}
$$

In the last stanza of the poem, the speaker seems to quite sarcastically expose the hypocrisy of the perpetrators of patriarchal violence whose hands are not defiled despite their tearing away of the phaneks of the 'untouchable' menstruating women during their "nocturnal" trysts or "daytime" assaults:

$$
\begin{gathered}
\text { Neither Nocturnal tryst nor daytime assault } \\
\text { Defiled the hands that tore it away } \\
\text { Yet lying apart from me }
\end{gathered}
$$$$
\text { In the pale weather-beaten bamboo polankhok }
$$

He watched the muga fabric

Soak up the rain

Droplet after droplet. (Phuritshabam et al., 2011, p. 18)

In Haripriya's "I died a little", the speaker records and questions the two-fold approach of the society regarding the body of women. The first stanza deals with the constitutive role of the droplet of menstrual blood at the onset of menarche in framing the social identity of a woman. The speaker says:

$$
\begin{gathered}
\text { The stained cloth } \\
\text { Became my flag } \\
\text { I was congratulated } \\
\text { For reasons I knew not } \\
\text { My mother said }
\end{gathered}
$$

I was now a complete woman. (p. 22)

The speaker has been congratulated for having become a "complete woman" by having gone through the biological process of puberty, and the completeness of the woman is shown to hinge on that socio-biological factor. This brings to mind what Butler (1988) has said about how gender identity gets constructed through the gradual sedimentation of performative acts and their iteration. In bringing to the fore in an unabashed manner, the issues of the menstruating 'leaky body', the fluids emanating from which are always "subordinated to that which is concrete and solid" (Irigaray, 1985, p. 113), the speaker transgresses into a domain which has hitherto been tabooed and stigmatized by erasing its presence in speech and representation. In the process of reclaiming and rescuing the female body from patriarchal deprecation, the speaker exposes the ambivalence in the societal discourse that marks the droplets as "impure" while at the same time considering them as necessary for shaping the identity of a woman (Phuritshabam et al., 2011, p. 22). By foregrounding the menstruating body of the woman, the speaker also challenges the patriarchal notion of its "continuous concealment" since the phenomenon of menstruation "has 
been codifed as something uncontrollable that needs to be organized, managed, and contained" (Green-Cole, 2020, p. 788). The second stanza of the poem deals with the constitutive role of the "impure little droplets" in constructing the identity of the "He" in the social sphere (Phuritshabam et al., 2011, p. 22). The woman has been "deflowered" and the celebration of that process has also been validated and made possible by the secretion of those droplets (p. 22). The manhood of the lover is projected here as being dependent on the "impure little droplets", as he celebrates "being the first" to deflower the woman, this act becoming "his flag" which he wears "proudly around his neck" (p. 22).

In several other poems of the anthology, the body of the woman has, in a similar vein, been shown not only as a potential site for framing and shaping gender identities because it is, after all, as Bordo (2001) points out "a text of culture" and "a practical, direct locus of social control" (p. 2362, emphasis in original) but also as a tool for resisting its sexual colonization by the patriarchal mores which render female bodies as "docile bodies", regulated by the norms of cultural life (Foucault, 1979, p. 135). Whether it is a protest against the commodification of women's bodies, as we find in Phuritshabam's "Fruits of Your Taste", where an image of "the market of fruits" is evoked whereby women's bodies are likened to "[a]pples, oranges, grapes" from amongst which men can make a "choice" and can "lift and taste their juices" (Phuritshabam et al., 2011, p. 71), or whether it is an expression of the desire to let their bodies be "tattoed with all taboos" and let them "enjoy the most wanton of all dreams", as we find in Ningombam's "One Last Time" (Phuritshabam et al., 2011, p. 41), the three women poets of Tattooed with Taboos attempt to transcend their subjected selves though their poetic endeavour by charting an alternative to the stifling patriarchal discourse, using the female body as tool of retaliation.

\section{References}

Arthur, Linda B. (1998). Deviance, Agency, and the Social Control of Women's Bodies in a Mennonite Community. NWSA Journal, Vol. 10, No. 2, 75-99. Retrieved from http://www.jstor.org/stable/4316579.

Butler, Judith. (1988). Performative Acts and Gender Constitution: An Essay in Phenomenology and Feminist Theory. Theatre Journal, Vol. 40, No. 4, pp. 519-531.

Davidson, K. (August 7 2015). Is Phanek Feminism the Right Feminist Struggle?: Reading Tattooed with Taboos, an Anthology of Poetry by Three Women Poets from Manipur. Retreived from htpp://epao.net.

Deshpande, Shashi. (1996). A Matter of Time. New Delhi: Penguin Books.

Foucault, M. (1979). Discipline and Punish: The Birth of the Prison. New York: Vintage.

Green-Cole, Ruth. (2020). Painting Blood: Visualizing Menstrual Blood in Art. In Bobel, Chris, Inga T. Winkler, Breanne Fahs, Katie Ann Hasson, Elizabeth Arveda Kissling \& Tomi-Ann Roberts (Eds.), The Palgrave Handbook of Critical Menstruation Studies (pp. 787-801). Singapore: Palgrave Macmillan.

Haripriya, Soibam. (2018). From the Shackles of Tradition: Motherhood and Women's Agitation in Manipur. In M. Vandenhelsken, M. Barkataki-Ruscheweyh, \& B. G. Karlsson (Eds.), Geographies of Difference: Explorations in Northeast Indian Studies (pp. 215-232). New York: Routledge.

Holmström, Lakshmi (Ed.). (1990). The Inner Courtyard: Stories by Indian Women. London; Virago Press. Irigaray, Luce. (1985). This Sex Which Is Not One. Ithaca, New York: Cornell University Press. 
9 Resisting Sexual Colonization, Reclaiming Denied Spaces: A Reading of Tattooed with Taboos: An Anthology of Poetry by Three Women from Northeast India

Jalil, Rakhshanda \& Debjani Sengupta (Eds.). (2019). Women's Writings from India, Pakistan and Bangladesh: The Worlds of Bangla and Urdu. New Delhi: Bloomsbury India.

Lorde, A. (2007). Sister Outsider: Essays and Speeches by Audre Lorde. New York, NY: Random House Inc.

Lupton, Mary Jane. (1993). Menstruation and Psychoanalysis. Urbana: University of Illinois Press.

Ningthoujam, Sianico. (16 July 2020). The Woman in Phanek: Various Contradictions of the Sacred Meitei Sarong. Retrieved from https://www.sahapedia.org/.

Phuritshabam, Chaoba, Shreema Ningombam \& Soibam Haripriya. (2011). Tattooed with Taboos: An Anthology of Poetry by Three Women from Northeast India. New Delhi: Partridge India.

Reed, T. V. (2005). The Art of Protest. Minneapolis, MN: University of Minnesota Press.

Sabala \& Meena Gopal. (2010). Body, Gender and Sexuality: Politics of Being and Belonging. Economic and Political Weekly, April 24-30, Vol. 45, No. 17, pp. 43-51. Retrieved from http://www.jstor.com/stable/25664384.

Tharu, Susie \& K. Lalita (Eds.). (1993). Women Writing in India: 6oo B.C. to the Present. The Twentieth Century (Vol. 2). New York: Feminist Press. 